\title{
Dreams of yarrow
}

I dreamed of twining yarrow

with the scent of blood.

Snow at my feet,

I harvested almost silently

against grey sky.

In my mittened palms I could see

the buds almost burst with the cold.

I pulled whole arms full of the tender plant, carried it home in my pockets,

in my sleep.

I covered the stems in oil,

the flowers in water,

stored the bounty in lidded jars.

Essence to take from wooden spoons.

Salve to be rubbed into ache.

I shelved the jars

next to the rows of other dreams-

a cellar full of medicine for the splits of winter.

Already here, the cellar keeps the jars warm

and humming with images not quite forgotten.

And, I can taste the residue of gathering,

alone with my collection,

waiting for the opening of eyes,

the baring of skin.

Only the sound of roots

and the gentle prediction

for more snow. 